
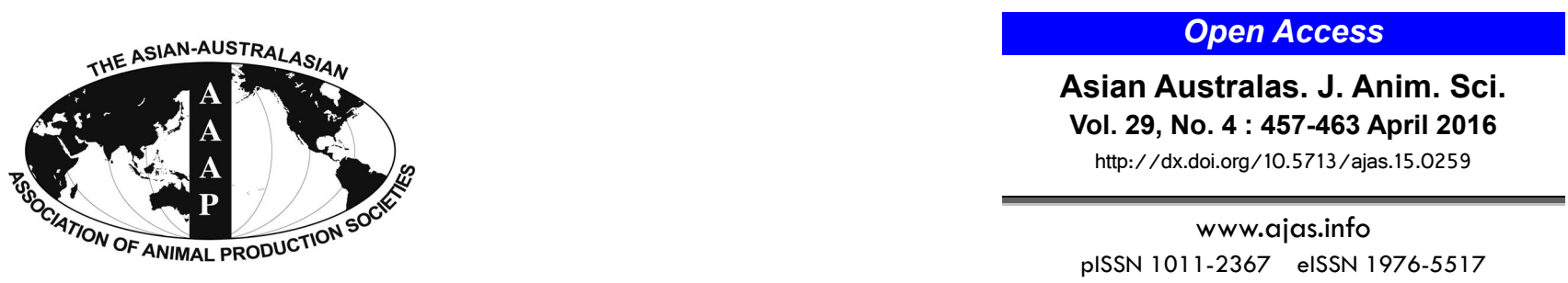

\title{
Association Analysis of Myosin Heavy-chain Genes mRNA Transcription with the Corresponding Proteins Expression of Longissimus Muscle in Growing Pigs
}

\author{
X. M. Men, B. Deng, X. Tao, K. K. Qi, and Z. W. Xu* \\ Institute of Animal Husbandry and Veterinary Science, Zhejiang Academy of Agricultural Science, \\ Hangzhou 310021, China
}

\begin{abstract}
The goal of this work was to investigate the correlations between MyHC mRNA transcription and their corresponding protein expressions in porcine longissimus muscle (LM) during postnatal growth of pigs. Five DLY (Duroc $\times$ Landrace $\times$ Yorkshire) crossbred pigs were selected, slaughtered and sampled at postnatal 7, 30, 60, 120, and 180 days, respectively. Each muscle was subjected to quantity MyHCs protein contents through an indirect enzyme-linked immunosorbent assay (ELISA), to quantity myosin heavy-chains (MyHCs) mRNA abundances using real-time polymerase chain reaction. We calculated the proportion (\%) of each MyHC to total of four MyHC for two levels, respectively. Moreover, the activities of several key energy metabolism enzymes were determined in LM. The result showed that mRNA transcription and protein expression of MyHC I, IIa, IIx and IIb in LM all presented some obvious changes with postnatal aging of pigs, especially at the early stage after birth, and their mRNA transcriptions were easy to be influenced than their protein expressions. The relative proportion of each MyHC mRNA was significantly positively related to that of its corresponding protein $(\mathrm{p}<0.01)$, and MyHC I mRNA proportion was positively correlated with creatine kinase (CK), succinate dehydrogenase $(\mathrm{SDH})$, malate dehydrogenase $(\mathrm{MDH})$ activities $(\mathrm{p}<0.05)$. These data suggested that MyHC mRNA transcription can be used to reflect MyHC expression, metabolism property and adaptive plasticity of porcine skeletal muscles, and MyHC mRNA composition could be a molecular index reflecting muscle fiber type characteristics. (Key Words: Myosin Heavy-chain, Myofiber Types, Gene Expression, Porcine Muscle)
\end{abstract}

\section{INTRODUCTION}

Mammalian skeletal muscle fibers are characterized by their morphological traits such as total number of fibers (TNF) and cross-sectional area of fibers (CSAF), and fiber type characteristics, such as contractile, and metabolic properties (Lee et al., 2010). During the postnatal growth process of pigs, there are no changes in TNF while the CSAF within muscle increases with aging. Fiber type characteristics can also change to accommodate a myriad of environmental cues (Gunawan et al., 2007), which contribute to variations of pork quality (Joo et al., 2013).

\footnotetext{
* Corresponding Author: Xu Zi Wei. Tel: +86-0571-8640-4398, Fax: +86-0571-8640-0836, E-mail: xzwfyz@sina.com Submitted Mar. 24, 2015; Revised Jul. 13, 2015; Accepted Aug. 24, 2015
}

Myosin heavy-chain (MyHC) is a major contractile apparatus in mammalian skeletal muscles, and consists of different types of protein isoforms. According to $\mathrm{MyHC}$ isoform composition, four different types of muscle fiber exists in adult porcine muscle, including slow-oxidative, fast-oxidative, intermediate and fast-glycolytic myofibres (Schiaffino et al., 1989). Compared with MyHC protein expression, studying MyHC mRNA transcription is more beneficial in understanding the transamination mechanism among different fiber types, and the corresponding quantitative technique is also more valuable to identify changes in MyHC mRNA level (Jankala et al., 1997). However, not all of genes are controlled at the transcriptional level, the expression of some genes is also regulated by posttranscriptional regulation processes such as mRNA stability, translation initiation, and protein 
stability (Chen et al., 2002; Tian et al., 2004). Although MyHC mRNA transcription and protein expression are both used to reflect fiber type characteristics in porcine muscle (Schiaffino and Reggiani, 1996; Botinelli and and Reggiani, 2000; Spangenburg and Booth, 2003), further verification is required to determine whether MyHC mRNA transcription can reflect fiber type characteristics, especially in porcine muscles. At present, little researches has been carried out on the relationship between MyHC mRNA and the corresponding protein in muscle during postnatal growth process of pigs.

One major purpose of the present work is to reveal the correlations between MyHC mRNA transcription and the corresponding protein expression, through determining their dynamic changes in muscle during postnatal development and aging of pigs, and to develop an index reflecting muscle fiber type characteristics. These results would be a benefit for further utilizing $\mathrm{MyHC}$ to research porcine muscle fiber type characteristics on molecular level, and may provide potential ways to improve pork quality during postnatal growth.

\section{MATERIALS AND METHODS}

\section{Animals, housing, and experimental design}

All procedures for the care and use of pigs were approved by the animal ethics committee of Zhejiang Academy of Agricultural Science, China. We selected 25 male DYL (Duroc $\times$ Yorkshire $\times$ Landrace) newborn piglets from five litters (five pigs each litter) fed in Lvjia Yuan Livestock Industry Co., Ltd, Zhejiang Province, China. According to the nutritional requirement recommended by NRC (1998), these pigs were creep fed after birth with a creep diet, and weaned on day 28 , successively fed until 180-day age. All pigs were housed in a barn with enough space and given a free choice access to diets and tap water. In order to reveal the effects of postnatal growth stages on MyHC expression, we selected several key ages including postnatal 7 days $(2.50 \pm 0.15 \mathrm{~kg}$, representing the primary stage of piglets), 30 days $(10.00 \pm 0.50 \mathrm{~kg}$, representing the beginning of weaning stage), 60 days $(20.00 \pm 0.55 \mathrm{~kg}$, representing the last nursing stage), 120 days $(60.00 \pm 0.45$ $\mathrm{kg}$, representing the end of growing stage) and 180 $(100.00 \pm 0.60 \mathrm{~kg}$, representing the end of finishing stage) days, and five pigs of each stage were slaughter and sampled. These stages can reflect the changing physiological and in vitro environment of pigs during postnatal growth process, including muscle fiber characteristics.

\section{Sampling longissimus muscle}

According to the commercial live pig slaughtering rules in China, the pigs ready for slaughter were kept off feed and given a free access to tap water for 16 hours, and then killed through electrical stunning and exsanguination. About 5cm-thick longissimus muscle (LM) adjacent to the last rib was collected from the left side of the carcass within $30 \mathrm{~min}$ after exsanguination, and was rapidly frozen in liquid nitrogen and then stored in $-80^{\circ} \mathrm{C}$ until analysis.

\section{Analysizing protein expressions of four adult $\mathrm{MyHC}$ genes in longissimus muscle}

Myosion protein was extracted as described by Savolainen et al. (1995). About 200-mg LM tissue from each pig was powered in liquid nitrogen, and oscillated while added to $1.4 \mathrm{~mL}$ buffer solution $\mathrm{pH} 6.5$ containing 0.3 $\mathrm{M} \mathrm{KCl}, 0.1 \mathrm{M} \quad \mathrm{KH}_{2} \mathrm{PO}_{4}, 0.05 \mathrm{M} \mathrm{K}_{2} \mathrm{HPO}_{4}, 0.04 \mathrm{M}$ ethylenediaminetetraacetic acid disodium salt. The extracted mix was placed in ice bath for $15 \mathrm{~min}$, and the supernatant was collected by centrifuging at $3,000 \times \mathrm{g}$ for 10 $\min$ at $4^{\circ} \mathrm{C}$. A $100-\mu \mathrm{L}$ aliquot of supernatant was taken to measure total protein concentration with a protein assay kit (micro BCA, Shanghai Sangon Biological Engineering Technology and Services Co., Ltd., Shanghai, China).

The concentration of each MyHC was determined by an USCNLIFETM ELISA kit produced by Wuhan EIAab Technology Co., Ltd, Wuhan, China. The recombinant protein of each MyHC with different concentrations $(0,15$, $30,60,120,240,480$, and $960 \mathrm{pg} / \mathrm{mL}$ ) as a quality control was used to establish a linear regression equation for a quantitative assay. $100-\mu \mathrm{L}$ supernatant or the quality controls and $50 \mu \mathrm{L}$ labeling mouse anti-pig $\mathrm{IgG}$ with horseradish peroxides were successively added into 96well micro plate coated by specific antibody (MyHC I: A4.840, sc-53089; MyHC IIa: A4.1519, sc-53094; MyHC IIx: A4.1025, sc-53088; MyHC IIb: MY-32, Sc-58797). The micro plate was incubated for $1 \mathrm{~h}$ at $37^{\circ} \mathrm{C}$, and then washed by a washing buffer. Color reaction was conducted by successively adding $50 \mu \mathrm{L}$ coloured solution A and B for 15 $\mathrm{min}$, and then stopped by adding $50 \mu \mathrm{L}$ terminating solution. Optic density at $450 \mathrm{~nm}\left(\mathrm{OD}_{450} \mathrm{~nm}\right)$ was measured using Infinite 200 plate reader (TECAN, Switzerland). The contents of MyHC protein in unknown sample were calculated according to a linear regression equation fitted with the concentrations of quality controls and their corresponding $\mathrm{OD}_{450 \mathrm{~nm}}$, and expressed as "pg/mg protein". $\mathrm{MyHC}$ protein composition, the proportion of each $\mathrm{MyHC}$ protein to total of four MyHC, was calculated as follow:

$$
\frac{\text { MyHCIorIIaorIIborIIx }}{M y H C(I+I I a+I I b+I I x)} \times 100 \%
$$

Analysing mRNA transcriptions of four adult $\mathrm{MyHC}$ genes in longissimus muscle

Total RNA in tissue was isolated using an EZNA HP 
Total RNA kit (Omega Bio-tek, Norcross, GA, USA). The cDNA was passed through a reverTra Ace qPCR RT kit (Toyobo Co. Ltd., Osaka, Japan), with $3 \mu \mathrm{L}$ total RNA (about $2 \mu \mathrm{g}$ ), $1 \mu \mathrm{L}$ primer mix, $1 \mu \mathrm{L}$ RT enzyme mix, $4 \mu \mathrm{L}$ $5 \times \mathrm{RT}$ buffer, $13 \mu \mathrm{L}$ nuclease-free water. The mixture was incubated at $65^{\circ} \mathrm{C}$ for $2 \mathrm{~min}$, at $37^{\circ} \mathrm{C}$ for $15 \mathrm{~min}$, and then at $98^{\circ} \mathrm{C}$ for $5 \mathrm{~min}$, and last remained at $-80^{\circ} \mathrm{C}$ until being analysed.

Standard mRNA fragments for MyHC I, IIa, IIx and IIb were produced as described by $\mathrm{Hu}$ et al. (2008). The primers used were as follows: MyHC I F: 5'CACTTGCTAAGAGGGACCTCTGAGTTCA-3', U75316; MyHCIIa F: 5'-AGCCTCTTTCTTCTCCCAGGGACATTC3', AB025260; MyHC IIb F: 5'-CATCTGGTAACATAA GAGGTACATCTAG-3', AB025261; MyHCIIx F: 5'CTTTCCTCATAAAGCTTCAAGTTCTGCC-3', AB025262; MyHCs R: ATCCAGGCTGCGTAACGCTCTTTGAGGTT GTA, and were synthesized by Invitrogen Co. Ltd., Shanghai, China. The molecular number of each standard mRNA fragment was calculated according to "copies $/ \mu \mathrm{L}=$ $6.02 \times 10^{23}($ copies $/ \mathrm{mol}) \times 10^{-9} \times$ concentration $(\mathrm{ng} / \mu \mathrm{L}) / \mathrm{RNA}$ length (base numbers) $\times 340$ (g/mol/base)". The standard mRNA fragments were divided into multiples of 10 to $10^{4} \sim 10^{8}$ copies $/ \mu \mathrm{L}$, and then reverse transcribed into cDNA which was used to fit a standard curve of real-time polymerase chain reaction (PCR). The PCR reaction mixture used the SYBR qPCR Mix kit (Toyobo Co., Ltd., Japan) in a volume of $15 \mu \mathrm{L}$ consisting of $0.3 \mu \mathrm{L}$ of each primer $(10 \mathrm{nM}), 7.5 \mu \mathrm{L}$ SYBR qPCR mix, $0.3 \mu \mathrm{L}$ ROX reference dye, $2.0 \mu \mathrm{L}$ cDNA and $4.6 \mu \mathrm{L}$ (Easy dilution). The reaction was carried out in a StepOne Plus Real-time PCR system (Life Technologies, Carlsbad, CA, USA) for $20 \mathrm{~s}$ at $95^{\circ} \mathrm{C}$, followed by 40 cycles at $95^{\circ} \mathrm{C}$ for $5 \mathrm{~s}$ and $60^{\circ} \mathrm{C}$ for 50 $\mathrm{s}$. The molecular numbers of each MyHC mRNA in a muscle sample (copies/mg tissue) was calculated according to the fitted standard curves. MyHC mRNA composition, the proportion of each MyHC mRNA to total of four MyHC, was calculated as MyHC protein composition.

\section{Analysing of metabolic enzymes activities in LM}

Frozen muscle tissues were weighed, homogenized in normal saline $(0.9 \%)$ and centrifuged with $3,500 \times g$ for 10 min at $4^{\circ} \mathrm{C}$. The supernatant was used to measure total protein concentration as described in the above section "Analyzing protein expressions of four $M y H C$ genes in LM". Another $400-\mu \mathrm{L}$ supernatant was used to measure succinate dehydrogenase (SDH), malate dehydrogenase $(\mathrm{MDH})$, creatine kinase $(\mathrm{CK})$ and lactate dehydrogenase (LDH) activities using commercial kits (Nanjing Jiangcheng Biochemical Institute, Nanjing, China). The enzyme activities were expressed as "U/mg protein".

\section{Statistical analyses}

A one-way analysis of variance and Duncan test $(\mathrm{p}=$ 0.05) in SPSS16.0 was employed to determine the differences among means from different ages, and all data were expressed as "means \pm standard deviation (stdv.)". Association analysis was conducted by Pearson correlation coefficients of bivariate correlations in SPSS16.0.

\section{RESULTS}

\section{Dynamics changes of MyHC I, IIa, IIx, and IIb protein expressions}

In Table 1, MyHC I protein content and relative proportion both significantly decreased in the order of "7 days $\rightarrow 30$ days, 60 days $\rightarrow 120$ days, 180 days" $(p<0.05)$. MyHC IIa protein content and MyHC IIx protein relative proportions did not significantly change from 30 to 180 days $(p>0.05)$, which were significantly higher than that at 7 days $(\mathrm{p}<0.05)$. MyHC IIa protein relative proportion and MyHC IIx protein content both exhibited a tendency of increasing first and decreasing afterwards, and the highest value at 30 days from 7 to 180 days $(\mathrm{p}<0.05)$. MyHC IIb protein content and relative proportion both decreased first and increased afterwards, with the lowest value at 30 days during postnatal growth $(\mathrm{p}<0.05)$.

\section{Dynamics changes of MyHC I, IIa, IIx, and IIb mRNA transcriptions}

In Table 2, MyHC I mRNA abundance and relative

Table 1. Comparison of MyHC protein expression in LM of pigs with different postnatal ages

\begin{tabular}{|c|c|c|c|c|c|c|}
\hline & & 7 days & 30 days & 60 days & 120 days & 180 days \\
\hline \multirow[t]{2}{*}{ МyHC I } & Contents (pg/mg) & $9.83 \pm 0.51^{\mathrm{a}}$ & $7.71 \pm 0.66^{b}$ & $7.95 \pm 1.52^{b}$ & $5.75 \pm 0.36^{\mathrm{c}}$ & $6.02 \pm 0.96^{\mathrm{c}}$ \\
\hline & Relative proportion (\%) & $12.19 \pm 0.76^{\mathrm{a}}$ & $9.74 \pm 1.00^{\mathrm{b}}$ & $7.86 \pm 1.55^{\mathrm{b}}$ & $5.96 \pm 0.33^{\mathrm{c}}$ & $6.15 \pm 0.80^{\mathrm{c}}$ \\
\hline \multirow[t]{2}{*}{ MyHC IIa } & Contents $(\mathrm{pg} / \mathrm{mg})$ & $12.36 \pm 1.43^{\mathrm{b}}$ & $25.03 \pm 1.94^{\mathrm{a}}$ & $26.94 \pm 2.37^{\mathrm{a}}$ & $22.64 \pm 2.19^{\mathrm{a}}$ & $25.37 \pm 4.52^{\mathrm{a}}$ \\
\hline & Relative proportion (\%) & $18.74 \pm 4.02^{\mathrm{b}}$ & $32.28 \pm 0.99^{\mathrm{a}}$ & $16.30 \pm 0.25^{\mathrm{b}}$ & $19.88 \pm 1.55^{\mathrm{b}}$ & $23.84 \pm 3.55^{\mathrm{b}}$ \\
\hline \multirow[t]{2}{*}{ МyHC IIx } & Contents (pg/mg) & $15.11 \pm 3.11^{\mathrm{c}}$ & $25.59 \pm 1.38^{\mathrm{a}}$ & $16.51 \pm 1.26^{\mathrm{c}}$ & $19.47 \pm 1.67^{\mathrm{b}}$ & $23.24 \pm 2.91^{\mathrm{a}}$ \\
\hline & Relative proportion (\%) & $15.30 \pm 1.56^{\mathrm{b}}$ & $31.55 \pm 1.41^{\mathrm{a}}$ & $26.61 \pm 2.40^{\mathrm{a}}$ & $23.80 \pm 2.47^{\mathrm{a}}$ & $25.81 \pm 3.19^{\mathrm{a}}$ \\
\hline \multirow[t]{2}{*}{ MyHC IIb } & Contents $(\mathrm{pg} / \mathrm{mg})$ & $53.27 \pm 4.29^{\mathrm{a}}$ & $28.65 \pm 0.40^{\mathrm{b}}$ & $57.81 \pm 3.28^{\mathrm{a}}$ & $54.61 \pm 1.89^{\mathrm{a}}$ & $49.20 \pm 3.18^{\mathrm{a}}$ \\
\hline & Relative proportion (\%) & $65.96 \pm 4.32^{\mathrm{a}}$ & $36.18 \pm 1.03^{\mathrm{c}}$ & $57.09 \pm 2.97^{\mathrm{b}}$ & $56.62 \pm 1.08^{\mathrm{b}}$ & $50.35 \pm 3.22^{\mathrm{b}}$ \\
\hline
\end{tabular}

MyHC, myosin heavy-chain; LM, longissimus muscle.

Comparison of the data among different ages, the same letters mean no significant difference between them ( $>0.05$ ), the different letters mean the significant difference $(\mathrm{p}<0.05)$ 
Table 2. Comparison of MyHC mRNA transcription in LM of pigs with different postnatal ages

\begin{tabular}{llccccc}
\hline & & 7 days & 30 days & 60 days & 120 days & 180 days \\
\hline MyHC I & Abundance $\left(10^{9}\right.$ copies/mg) & $3.44 \pm 0.32^{\mathrm{a}}$ & $0.13 \pm 0.04^{\mathrm{c}}$ & $0.97 \pm 0.14^{\mathrm{b}}$ & $0.98 \pm 0.08^{\mathrm{b}}$ & $0.85 \pm 0.08^{\mathrm{b}}$ \\
& Relative proportion (\%) & $3.47 \pm 0.73^{\mathrm{a}}$ & $0.25 \pm 0.07^{\mathrm{d}}$ & $1.49 \pm 0.25^{\mathrm{b}}$ & $1.25 \pm 0.13^{\mathrm{b}}$ & $0.88 \pm 0.06^{\mathrm{c}}$ \\
MyHC IIa & Abundance $\left(10^{9}\right.$ copies/mg) & $0.49 \pm 0.19^{\mathrm{d}}$ & $3.14 \pm 0.91^{\mathrm{a}}$ & $1.03 \pm 0.10^{\mathrm{c}}$ & $1.58 \pm 0.55 \mathrm{~b}^{\mathrm{c}}$ & $2.44 \pm 0.94^{\mathrm{b}}$ \\
& Relative proportion (\%) & $1.18 \pm 0.46^{\mathrm{b}}$ & $6.06 \pm 1.67^{\mathrm{a}}$ & $1.59 \pm 0.19^{\mathrm{b}}$ & $2.02 \pm 0.74^{\mathrm{b}}$ & $2.54 \pm 1.01^{\mathrm{b}}$ \\
MyHC IIx & Abundance $\left(10^{9}\right.$ copies/mg) & $0.61 \pm 0.03^{\mathrm{b}}$ & $1.49 \pm 0.73^{\mathrm{a}}$ & $0.40 \pm 0.16^{\mathrm{c}}$ & $1.55 \pm 0.55^{\mathrm{a}}$ & $2.29 \pm 0.47^{\mathrm{a}}$ \\
& Relative proportion $(\%)$ & $1.47 \pm 0.05 \mathrm{~b}$ & $2.87 \pm 0.68 \mathrm{a}$ & $0.60 \pm 0.23 \mathrm{c}$ & $1.98 \pm 0.74 \mathrm{a}$ & $2.38 \pm 0.47 \mathrm{a}$ \\
MyHC IIb & Abundance $\left(10^{9}\right.$ copies $\left./ \mathrm{mg}\right)$ & $38.79 \pm 1.42^{\mathrm{e}}$ & $47.04 \pm 1.67^{\mathrm{d}}$ & $62.81 \pm 2.79^{\mathrm{c}}$ & $74.76 \pm 2.59^{\mathrm{b}}$ & $90.87 \pm 2.73^{\mathrm{a}}$ \\
& Relative proportion $(\%)$ & $93.87 \pm 0.93^{\mathrm{ab}}$ & $90.83 \pm 3.07^{\mathrm{b}}$ & $96.12 \pm 0.19^{\mathrm{a}}$ & $94.75 \pm 1.59^{\mathrm{a}}$ & $94.21 \pm 1.29^{\mathrm{a}}$ \\
\hline
\end{tabular}

MyHC, myosin heavy-chain; LM, longissimus muscle.

Comparison of the data among different ages, the same letters mean no significant difference between them ( $>0.05)$, the different letters mean the significant difference $(\mathrm{p}<0.05)$.

proportion both presented an obviously decreasing tendency in the order of "7 days $\rightarrow 60$ days $\rightarrow 120$ days $\rightarrow 180$ days $\rightarrow 30$ days", with the significant differences between 7 days and other days, 30 days and other days $(\mathrm{p}<0.05)$. MyHC IIa and IIx mRNA both exhibited a tendency of increasing first and decreasing afterwards in both their absolute contents and relative proportions, with the lowest value at 7 days for MyHC IIa mRNA and at 60 days for MyHC IIx mRNA. MyHC IIb mRNA abundance gradually increased with postnatal aging $(\mathrm{p}<0.05)$, whereas its relative proportion had a non-significant change between 7 and 30 days, and then significantly increased from 60 days on $(p<0.05)$.

Correlations of MyHC mRNA transcriptions with the corresponding protein expressions during postnatal growth

Table 3 showed that, for any $M y H C$ gene, mRNA relative proportion was highly significantly positively correlated with the corresponding protein proportion $(\mathrm{p}<0.01)$. But not all of positive correlation was significant $(\mathrm{p}<0.05)$, between MyHC mRNA abundance and its protein content.

\section{Correlations between MyHC composition and metabolic enzymes activities in LM}

Table 4 shows the activities of four metabolism enzymes in LM of pigs from different postnatal ages. The activities of $\mathrm{MDH}$ and $\mathrm{SDH}$ presented an obviously decreasing tendency from 7 to 180 days, with the significant differences between 7 days and other days, 3060 days and other days $(\mathrm{p}<0.05)$. CK activity at 7 days was higher than that of other days $(p<0.05)$, and there was no significantly difference from 7 to 180 days for LDH activity $(\mathrm{p}>0.05)$.

In Table 5, the relative proportions of MyHC I mRNA and protein were both positively correlated with the activities of $\mathrm{SDH}$ and $\mathrm{MDH}(\mathrm{p}<0.01)$. The relative proportion of MyHC I mRNA was also positively correlated

Table 3. Correlations of MyHC mRNA transcription with its protein expression in porcine LM during postnatal growth

\begin{tabular}{|c|c|c|c|c|c|c|c|c|c|}
\hline & \multicolumn{4}{|c|}{ MyHC protein content } & & \multicolumn{4}{|c|}{ MyHC protein composition } \\
\hline & MyHC I & MyHC IIa & MyHC IIx & MyHC IIb & & MyHC I & MyHC IIa & MyHC IIx & MyHC IIb \\
\hline \multicolumn{5}{|c|}{ MyHC mRNA abundance } & \multicolumn{5}{|c|}{ MyHC mRNA composition } \\
\hline MyHC I & 0.334 & - & - & - & MyHC I & $0.576^{* *}$ & - & - & - \\
\hline MyHC IIa & - & $0.458 *$ & - & - & MyHC IIa & - & $0.652 * *$ & - & - \\
\hline MyHC IIx & - & - & $0.637 * *$ & - & MyHC IIx & - & - & $0.753 * *$ & - \\
\hline MyHC IIb & - & - & - & 0.288 & MyHC IIb & - & - & - & $0.551 * *$ \\
\hline
\end{tabular}

MyHC, myosin heavy-chain; LM, longissimus muscle.

* Means significant difference $(\mathrm{p}<0.05)$; ** means very significant difference $(\mathrm{p}<0.01)$.

Table 4. Comparison of metabolic enzymes activities in LM of pigs with different postnatal ages

\begin{tabular}{lccccc}
\hline Metabolic enzymes activities & 7 days & 30 days & 60 days & 120 days & 180 days \\
\hline Creatine kinase, CK & $16.69 \pm 2.84^{\mathrm{a}}$ & $11.98 \pm 1.99^{\mathrm{b}}$ & $8.76 \pm 3.90^{\mathrm{b}}$ & $12.16 \pm 1.80^{\mathrm{b}}$ & $10.21 \pm 1.44^{\mathrm{b}}$ \\
Lactate dehydrogenase, $\mathrm{LDH}$ & $24.09 \pm 4.67$ & $19.63 \pm 5.18$ & $26.80 \pm 6.25$ & $25.39 \pm 4.25$ & $28.07 \pm 4.76$ \\
Succinate dehydrogenase, $\mathrm{SDH}$ & $11.78 \pm 2.06^{\mathrm{a}}$ & $5.78 \pm 0.92^{\mathrm{b}}$ & $5.01 \pm 1.63^{\mathrm{b}}$ & $2.62 \pm 0.61^{\mathrm{c}}$ & $2.16 \pm 0.51^{\mathrm{c}}$ \\
Malate dehydrogenase, $\mathrm{MDH}$ & $2.24 \pm 1.17^{\mathrm{a}}$ & $1.47 \pm 0.20^{\mathrm{b}}$ & $1.24 \pm 0.20^{\mathrm{b}}$ & $0.76 \pm 0.07^{\mathrm{c}}$ & $0.77 \pm 0.07^{\mathrm{c}}$ \\
\hline
\end{tabular}

LM, longissimus muscle.

Comparison of the data among different ages, the same letters mean no significant difference between them ( $>0.05$ ), the different letters mean the significant difference $(\mathrm{p}<0.05)$. 
with CK activity $(\mathrm{p}<0.01)$, while the protein relative proportion was negatively correlated with $\mathrm{LDH}$ activity $(\mathrm{p}<0.01)$.

\section{DISCUSSION}

\section{Expressions of four adult $\mathrm{MyHC}$ genes in postnatal porcine muscle}

MyHC are encoded by a multigene family in skeletal muscle of mammalian animals. Eleven $M y H C$ genes have been found in different types of muscle tissue such as skeletal muscle and cardiac muscle. MyHC-neo and MyHC$e m b$ genes are only expressed before birth of animals, while MyHCI, IIa, IIx, and IIb are expressed in skeletal muscles of adult animals (Schiaffino and Reggiani, 2011). Early reports have indicated that MyHC were expressed in a tissue-specific and developmentally regulated manner in muscle (Mahdavi et al., 1987).

The present study found that mRNA transcription and protein expression of four adult $M y H C$ genes all presented some obvious changes with postnatal aging of pigs, especially in the early stage. The result was in agreement with that reported in the literature (Zhao et al., 2004; Yang et al., 2008). The phenomenon could be related with the special developmental stage, dietary changing, and weaning stress. Because in a single myofibre, several types of MyHC isoforms simultaneously exist, and can reverse from one form to another so that a special myofibre may be dominated by a particular MyHC isoform in a specific environment (Reggiani et al., 2000). The phenotypic properties of skeletal muscle fibers can be influenced by various factors such as development, innervation, increased and decreased neuromuscular activity, physical activity (overloading and unloading), hormones and ageing (Sullivan et al., 1995; Schiaffino and Reggiani, 1996; Pette and Staron, 2000). In our result, MyHC IIb and IIx of LM in 30 days and 60 days had the lowest expressions. These could be related to weaning stress of piglets. Weaning stress produced effects on feed intake, growth performance and some endocrine indexes in piglets, such as thyroid hormone and insulin-like growth factor. For skeletal muscle, these growth factors mediate the formation of fast-type myofibers (MusarÒ, et al., 2001; Lynch, et al., 2001). Certainly, effects of weaning on muscle fiber types was very complex and needs to be further researched. Our result only indicated that muscle fibers have the highly adaptability and plasticity for different environmental changes. Moreover, MyHC mRNA changed more sensitively than MyHC protein in muscle with the postnatal aging of pigs in present study. This further confirmed existed previous report that the major regulation of $\mathrm{MyHC}$ expression may occur at the mRNA transcriptional level (Cox and Buckingham, 1992).

\section{Correlations between mRNA transcription and protein expression of $\mathrm{MyHC}$}

In human muscle, MyHC protein levels have been confirmed to be positively correlated with mRNA transcript (Short et al., 2005). Gunawan et al. (2007) found that the relative expressive level of MyHC I or IIb mRNA was positively correlated with relative content of the corresponding protein to total content of four MyHC isoforms protein $\left(\mathrm{R}^{2}=0.76\right.$ and 0.78 , respectively) in various muscles from seven pigs.

The present study respectively determined the mRNA and protein absolute levels of MyHC I, IIa, IIx, and IIb in porcine muscle tissue, through an absolute quantitative realtime PCR and an indirect enzyme-linked immunosorbent assay, and then calculated the relative proportion (\%) of each MyHC to total four MyHC. Our results found a positive correlation between mRNA transcriptions and protein expressions in any of the four $M y H C$ genes, including their abundant contents and relative proportions. Especially, the correlation coefficients (r) between the relative proportion of $\mathrm{mRNA}$ and that of the corresponding protein ranged from 0.551 to 0.753 , and were highly significant. These also confirmed that MyHC expression is transcriptionally regulated (Cox and Buckingham, 1992).

\section{Quantitative analysis of MyHC expressions and fiber type characteristics in muscle}

Some researches regarded $\mathrm{MyHC}$ expressions as a powerful tool for analyzing fibre type characteristics of muscles (Schiaffino and Reggiani, 1996); Spangenburg and Booth, 2003). Multiple immunochemistry, sodium dodecyl sulfate-polyacrylamide gel electrophoresis (SDS-PAGE) and proteomics were used to study MyHC protein

Table 5. Correlations of MyHC composition with metabolism enzyme activities in porcine LM during postnatal growth

\begin{tabular}{|c|c|c|c|c|c|c|c|c|}
\hline & \multicolumn{4}{|c|}{ MyHC protein composition } & \multicolumn{4}{|c|}{ MyHC mRNA composition } \\
\hline & MyHC I & MyHC IIa & MyHC IIb & MyHC IIx & MyHC I & MyHC IIa & MyHC IIb & MyHC IIx \\
\hline CK activity & 0.224 & -0.247 & -0.234 & -0.250 & $0.500 *$ & -0.128 & 0.041 & 0.105 \\
\hline LDH activity & $-0.468 *$ & 0.291 & 0.256 & 0.292 & 0.063 & -0.231 & 0.284 & -0.039 \\
\hline SDH activity & $0.643 * *$ & $-0.459 *$ & $-0.454 *$ & $-0.455^{*}$ & $0.769 * *$ & -0.143 & -0.126 & -0.185 \\
\hline MDH activity & $0.725 * *$ & $-0.474^{*}$ & $-0.467^{*}$ & $-0.470^{*}$ & $0.682 * *$ & -0.084 & -0.186 & -0.203 \\
\hline
\end{tabular}

MyHC, myosin heavy-chain; LM, longissimus muscle; CK, creatine kinase; LDH, lactate dehydrogenase; SDH, succinate dehydrogenase; MDH, malate dehydrogenase.

* Means significant difference $(\mathrm{p}<0.05) ; * *$ means very significant difference $(\mathrm{p}<0.01)$. 
expression (Caiozzo et al., 2004; Li et al., 2005), while slot/dot-blot (Diffee et al., 1991), northern blot (Caiozzo et al., 1996), RNase protection assay (Reilly et al., 2000), in situ hybridization (Serrano et al., 2001), and reverse transcriptase reaction coupled to a RT-PCR (Sanchez et al., 2006) were used to determine mRNA transcription. Immunochemistry and SDS-PAGE were regarded as the best semi-quantitative techniques for $\mathrm{MyHC}$ protein expression, but they may over-represent predominant proteins and under-represent small amounts of protein (Jankala et al., 1997). With the development of real time RT-PCR technique, quantification of MyHC mRNA could be a more valuable technique to identify changes in MyHC expression (Van Daele, 2010).

According to the metabolic properties of different types (I, IIa, IIx, IIb) of muscle fiber in adult porcine skeletal muscle, type I fibers are classically known to have greater oxidative capacity than type II fibers (Lefaucheur and Gerrard, 2000), which can be reflected in the activity of SDH or MDH. The present study showed that the activities of SDH, CK, and MDH were positively correlated with the compositions of MyHC I mRNA or protein. Thus, MyHC mRNA composition maybe an ideal index reflecting fiber type characteristics in porcine muscle. And we had utilized MyHC mRNA composition as a molecular marker of muscle fiber type composition within skeletal muscle, and revealed the age-related changes and nutritional regulation of myofibre type characteristics of porcine muscle in another paper (Men et al., 2013).

\section{CONCLUSION}

This study was the first to reveal the correlation between mRNA transcription and the corresponding protein expression of four adult $\mathrm{MyHC}$ genes in muscle, during postnatal aging of pigs. Data from these experiments suggested that MyHC mRNA transcription can be used to reflect myofibre type characteristics such as MyHC expression, metabolism property and adaptive plasticity of porcine skeletal muscles, and MyHC mRNA composition could be as an ideal index reflecting fiber type characteristics. Moreover, it will be necessary to investigate the correlation of MyHC mRNA composition with lipid and energy metabolism, and some key functional genes expression in muscle with the postnatal aging of pigs. This information would be useful for further understanding the biological mechanism of porcine skeletal muscle growth and meat quality development and may provide some effective approaches to improve pork quality.

\section{CONFLICT OF INTEREST}

We certify that there is no conflict of interest with any financial organization regarding the material discussed in the manuscript.

\section{ACKNOWLEDGMENTS}

This work was supported by the National Natural Science Foundation of China (31172220), the Science and Technology Projects in Zhejiang Province of China (2012C12906-4, 2010R50027-21), and the Modern Agroindustry Technology Research System of China (CARS-36).

\section{REFERENCES}

Bottinelli, R. and C. Reggiani. 2000. Human skeletal muscle fibres: molecular and functional diversity. Prog. Biophys. Mol. Biol. 73:195-262.

Caiozzo, V. J., F. Haddad, M. J. Baker, and K. M. Baldwin. 1996. Influence of mechanical loading on myosin heavy-chain protein and mRNA isoform expression. J. Appl. Physiol. 80:1503-1512.

Caiozzo, V. J., Y. Z. Wu, M. J. Baker, and R. Crumley. 2004. Effects of denervation on cell cycle control in laryngeal muscle. Arch. Otolaryngol. Head Neck Surg. 130:1056-1068.

Chen, G., T. G. Gharib, C-C. Huang, J. M. G. Taylor, D. E. Misek, S. L. R. Kardia, T. J. Giordano, M. D. Iannettoni, M. B. Orringer, S. M. Hanash, and D. G. Beer. 2002. Discordant protein and mRNA expression in lung adenocarcinomas. Mol. Cell. Proteomics 1:304-313.

Cox, R. D. and M. E. Buckingham. 1992. Actin and myosin genes are transcriptionally regulated during mouse skeletal muscle development. Dev. Biol. 149:228-234.

Diffee, G. M., F. Haddad, R. E. Herrick, and K. M. Baldwin. 1991. Control of myosin heavy chain expression: interaction of hypothyroidism and hindlimb suspension. Am. J. Physiol. 261: C1099-C1106.

Gunawan, A. M., S. K. Park, J. M. Pleitner, L. Feliciano, A. L. Grant, and D. E. Gerrard. 2007. Contractile protein content reflects myosin heavy-chain isoform gene expression. J. Anim. Sci. 85:1247-1256.

Hu, H. M., J. Y. Wang, R. S. Zhu, J. F. Guo, and Y. Wu. 2008. Effect of myosin heavy chain composition of muscles on meat quality in Laiwu pigs and Duroc. Sci. China. Series C, Life Sci. 51:127-132.

Jankala, H., V. P. Harjola, N. E. Petersen, and M. Harkonen. 1997. Myosin heavy chain mRNA transform to faster isoforms in immobilized skeletal muscle: A quantitative PCR study. J. Appl. Physiol. 82:977-982.

Joo, S. T., G. D. Kim, Y. H. Hwang, and Y. C. Ryu. 2013. Control of fresh meat quality through manipulation of muscle fiber characteristics. Meat Sci. 95:828-836.

Lee, S. H., S. T. Joo, and Y. C. Ryu. 2010. Skeletal muscle fiber type and myofibrillar proteins in relation to meat quality. Meat Sci. 86:166-170.

Lefaucheur, L. and D. E. Gerrard. 2000. Muscle fiber plasticity in farm mammals. J. Anim. Sci. 77(E-Suppl):1-19.

Li, Z. B., M. Lehar, R. Samlan, and P. W. Flint. 2005. Proteomic analysis of rat laryngeal muscle following denervation. Proteomics 5:4764-4776. 
Lynch, G. S., S. A. Cuffe, D. R. Plant, and P. Gregorevic. 2001. IGF-I treatment improves the functional properties of fast- and slow-twitch skeletal muscles from dystrophic mice. Neuromuscul. Dis. 11:260-268.

Mahdavi, V., S. Izumo, and B. Nadal-Ginard. 1987. Developmental and hormonal regulation of sarcomeric myosin heavy chain gene family. Circ. Res. 60:804-814.

Men, X. M., B. Deng, Z. W. Xu, X. Tao, and K. K. Qi. 2013. Agerelated changes and nutritional regulation of myosin heavychain composition in longissimus dorsi of commercial pigs. Animal 7:1486-1492.

MusarÒ, A., K. McCullagh, A. Paul, L. Houghton, G. Dobrowolny, M. Molinaro, E. R. Barton, H. L. Sweeney, and N. Rosenthal. 2001. Loclized Igf-1 transgene expression sustains hypertrophy and regeneration in senescent skeletal muscle. Nat. Genet. 27:195-200.

National Research Council. 1998. Nutrient Requirements of Swine. 10th Ed. National Academy Press, Washington, DC, USA.

Pette, D. and R. S. Staron. 2000. Myosin isoforms, muscle fiber types, and transitions. Microsc. Res. Tech. 50:500-509.

Reggiani, C., R. Bottinelli, and G. J. Stienen. 2000. Sarcomeric myosin isoforms: fine tuning of a molecular motor. News Physiol. Sci. 15:26-33.

Reilly, M. E., G. McKoy, D. Mantle, T. J. Peters, G. Goldspink, and V. R. Preedy. 2000. Protein and mRNA levels of the myosin heavy chain isoforms Ibeta, IIa, IIx and IIb in type I and type II fibre-predominant rat skeletal muscles in response to chronic alcohol feeding. J. Muscle Res. Cell Motil. 21:763-773.

Sanchez, H., R. Chapot, S. Banzet, N. Koulmann, O. Birot, A. X. Bigard, and A. Peinnequin. 2006. Quantification by real-time PCR of developmental and adult myosin mRNA in rat muscles. Biochem. Biophys. Res. Commun. 340:165-174.

Savolainen, J. and M. Vornanen. 1995. Myosin heavy chains in skeletal muscles of the common shrew (Sorex araneus): absence of a slow isoform and transitions of fast isoforms with ageing. Acta Physiol. Scand. 155:233-239.

Schiaffino, S., L. Gorza, S. Sartore, L. Saggin, S. Ausoni, M Vianello, K Gundersen, and T. Lømo. 1989. Three myosin heavy chain isoforms in type 2 skeletal muscle fibers. J. Muscle Res. Cell Motil. 10:197-205.
Schiaffino, S. and C. Reggiani. 1996. Molecular diversity of myofibrillar proteins: gene regulation and functional significance. Physiol. Rev. 76:371-423.

Schiaffino, S. and C. Reggiani. 2011. Fiber types in mammalian skeletal muscles. Physiol. Rev. 91:1447-1531.

Serrano, A. L., M. Murgia, G. Pallafacchina, E. Calabria, P. Coniglio, T. Lømo, and S. Schiaffino. 2001. Calcineurin controls nerve activity-dependent specification of slow skeletal muscle fibers but not muscle growth. Proc. Nat. Acad. Sci. USA. 98:13108-13113.

Short, K. R., J. L. A.Vittone, M. L. Bigelow, D. N. Proctor, J. M. Coenen-Schimke, P. Rys, and K. S. Nair. 2005. Changes in myosin heavy chain mRNA and protein expression in human skeletal muscle with age and endurance exercise training. J. Appl. Physiol. 99:95-102.

Spangenburg, E. E. and F. W. Booth. 2003. Molecular regulation of individual skeletal muscle fibre types. Acta Physiol. Scand.. 178:413-424.

Sullivan, V. K., S. K. Powers, D. S. Criswell, N. Tumer, J. S. Larochelle, and D. Lowenthal. 1995. Myosin heavy chain composition in young and old rat skeletal muscle: Effects of endurance exercise. J. Appl. Physiol. 78: 2115-2120.

Tian, Q., S. B. Stepaniants, M. Mao, L. Weng, M. C. Feetham, M. J. Doyle, E. C. Yi , H. Dai , V. Thorsson, J. Eng, D. Goodlett, J. P. Berger, B. Gunter, P. S. Linseley, R. B. Stoughton, R. Aebersold, S. J. Collins, W. A. Hanlon, and L. E. Hood. 2004. Integrated genomic and proteomic analyses of gene expression in mammalian cells. Mol. Cell. Proteomics 3:960-969.

Van Daele, D. J. 2010. Quantitative PCR analysis of laryngeal muscle fiber types. J. Commun. Disord. 43:327-334.

Yang, F. Y., D. W. Chen, J. X. Huang, and Z. H. Liu. 2008. Developmental changes of myofiber types in Longissimus Dorsi muscle of Rongchang and DLY Pigs under different nutrient condition. Chinese J. Anim. Vet. Sci. 39:1701-1708.

Zhao, R. Q., X. J. Yang, Q. F. Xu, X. H. Wei, D. Xia, J. Chen. 2004. Expression of GHR and PGC-1 alpha in association with changes of MyHC isoform types in longissimus muscle of Erhualian and Large White pigs (Sus scrofa) during postnatal growth. Anim. Sci. 79:203-211. 